\title{
Novel bioactive materials: silica aerogel and hybrid silica aerogel/pseudowollastonite
}

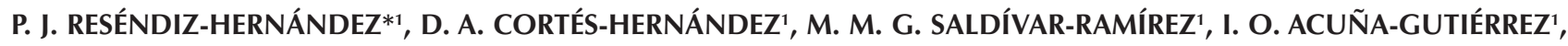 \\ A. FLORES-VALDÉS ${ }^{1}$, S. TORRES-RINCÓN² ${ }^{2}$ J. MÉNDEZ-NONELL ${ }^{1}$
}

\begin{abstract}
'CINVESTAV-IPN, Unidad Saltillo, Ave. Industria Metalúrgica 1062, Parque Industrial Saltillo-Ramos Arizpe, Ramos Arizpe, Coahuila 25900, México. ${ }^{2}$ CIQA, Centro de Investigación en Química Aplicada, Blvd. Enrique Reyna 140, Saltillo, Coahuila 25253, México. *Corresponding author: P.J. Reséndiz-Hernández. E-mail address: perla.resendiz@cinvestav.edu.mx, resendiz_perla@hotmail.com
\end{abstract}

\begin{abstract}
Silica aerogel and hybrid silica aerogel/pseudowollastonite materials were synthesized by controlled hydrolysis of tetraethoxysilane (TEOS) using also methanol $(\mathrm{MeOH})$ and pseudowollastonite particles. The gels obtained were dried using a novel process based on an ambient pressure drying. Hexane and hexamethyl-disilazane (HMDZ) were the solvents used to chemically modify the surface. In order to assess bioactivity, aerogels, without and with pseudowollastonite particles, were immersed in simulated body fluid (SBF) for 7 and 14 days. The hybrid silica aerogel/pseudowollastonite showed a higher bioactivity than that observed for the single silica aerogel. However, as in both cases a lower bioactivity was observed, a biomimetic method was also used to improve it. In this particular method, samples of both materials were immersed in SBF for 7 days followed by their immersion in a more concentrated solution (1.5 SBF) for 14 days. A thick and homogeneous bonelike apatite layer was formed on the biomimetically treated materials. Thus, bioactivity was successfully improved even on the aerogel with no pseudowollastonite particles. As expected, the hybrid silica aerogel/pseudowollastonite particles showed a higher bioactivity.
\end{abstract}

Keywords: Composites, Biomaterials, Bioceramics, Silica aerogel, Bioactivity.

Noveles materiales bioactivos: aerogel de sílice y aerogel híbrido de sílice/partículas de pseudowollastonita

Se sintetizaron aerogel de sílice y aerogel híbrido de sílice/partículas de pseudowollastonita por hidrólisis controlada de tetraetoxisilano (TEOS) usando metanol $(\mathrm{MeOH})$ y partículas de pseudowollastonita. Los geles obtenidos se secaron utilizando un novedoso proceso basado en una presión de secado ambiental. Hexano y hexametil-disilazano fueron los solventes usados para modificar químicamente la superficie. Para evaluar la bioactividad, los aerogeles con y sin partículas de pseudowollastonita se sumergieron en un fluido fisiológico simulado (SBF) por 7 y 14 días. El aerogel híbrido de sílice/ partículas de pseudowollastonita mostró más alta bioactividad que la observada por el aerogel solo. Sin embargo, en ambos casos, se observó una baja bioactividad, por lo que se utilizó un método biomimético para mejorarla. En este método particular, muestras de ambos materiales se sumergieron en SBF por 7 días seguido de su inmersión en una solución más concentrada (1.5 SBF) por 14 días. Se formó una capa gruesa y homogénea de apatita sobre los materiales tratados biomiméticamente. Por lo tanto, la bioactividad fue mejorada con éxito incluso en el aerogel sin partículas de pseudowollastonita. Como se esperaba, el aerogel híbrido de sílice con partículas de pseudowollastonita mostró la más alta bioactividad.

Palabras clave: Materiales compuestos. Biomateriales, Biocerámicas, Aerogel de silice, Bioactividad.

Cómo citar este artículo: Reséndiz-Hernández, P. J.; Cortés-Hernández, D. A.; Saldívar-Ramírez, M. M. G.; Acuña-Gutiérrez, I. O.; Flores-Valdés, A.; Torres-Rincón, S. y Méndez-Nonell, J. (2014): Novel bioactive materials: silica aerogel and hybrid silica aerogel/pseudowollastonite, Bol. Soc. Esp. Ceram. Vidr., 53 (5): 235-239. http:/ / dx.doi.org/10.3989/ cyv.282014

\section{INTRODUCTION}

Nowadays, silica aerogels have increasingly attracted more attention due to their extraordinary properties (1) and their existing and potential applications in a wide variety of technological areas (2). Silica aerogel is a nanostructured material with high specific surface area, high porosity, low density and low dielectric constant. Traditionally, the solvent in alcogel is removed by achieving supercritical stage to obtain the aerogels (3). However, a highly pursued goal in aerogel technology is the elimination of the supercritical drying step, since it is the most expensive process in the production of these materials.

On the other hand, materials that promote bone-tissue formation on their surface and bond to osseous tissues when implanted are known as bioactive materials (4-7). The role of silicon in the formation and maturation of bone has been established since the beginning of the 1970s (8-10). It is not 
TABLE I. ION CONCENTRATION OF SIMULATED BODY FLUIDS AND HUMAN BLOOD PLASMA (17).

\begin{tabular}{|c|c|c|c|c|c|c|c|c|}
\hline & $\mathbf{N a}^{+}$ & $\mathbf{K}^{+}$ & $\mathbf{M g}^{+2}$ & $\mathbf{C a}^{+2}$ & $\mathbf{C l}^{-}$ & $\mathbf{H C O}_{3}^{-}$ & $\mathbf{H P O}_{4}^{-2}$ & $\mathbf{S O}_{4}^{-2}$ \\
\hline SBF & 142 & 5.0 & 1.5 & 2.5 & 147.8 & 4.20 & 1.0 & 0.5 \\
\hline 1.5 SBF & 213 & 7.5 & 2.25 & 3.75 & 223.0 & 6.3 & 1.5 & 0.75 \\
\hline Human blood plasma & 142 & 5.0 & 1.5 & 2.5 & 103.0 & 27.0 & 1.0 & 0.5 \\
\hline
\end{tabular}

surprising that bioceramics that incorporate $\mathrm{Si}$ into their composition realize higher bioactivity. These include materials with very high $\mathrm{Si}$ levels such as pseudowollastonite $\left(\mathrm{CaSiO}_{3}\right)$ particles. Thus, Si-containing apatites ceramics are expected to be useful as biodegradable biomaterials to increase the speed of bony regeneration (11).

The bioactivity assessment can be performed by the immersion of samples in a simulated body fluid (SBF) with an ionic concentration nearly equal to that of human blood plasma. Biomimetic processes have been widely studied for growing a bone-like apatite layer on different substrates by using simulated body fluids with an ionic concentration higher than that of SBF $(12,13)$. The formation of this layer depends partially on the calcium and phosphorous ionic concentration in the vicinity of the immersed substrate. Thus, when the SBF is replaced during the biomimetic process or a more concentrated solution is used (1.5 SBF) the ionic concentrations will remain high, resulting in the formation of a hydroxyapatite layer by consuming calcium and phosphorous from the solution.

In the present work, silica aerogel and hybrid silica aerogels/pseudowollastonite materials were obtained by ambient pressure drying $(14,15)$ to eliminate the supercritical drying step. The materials received a surface treatment that induces the formation of a bioactive apatite layer on silica aerogel and hybrid silica aerogels/pseudowollastonite composites through a particular immersion method.

\section{EXPERIMENTAL}

\subsection{Preparation of silica aerogel and hybrid silica aerogel/ pseudowollastonite material}

Pseudowollastonite was synthesized by sol-gel under basic conditions using tetraethoxysilane (TEOS, Aldrich $98 \%$ purity) and calcium nitrate (Aldrich $99 \%$ purity) as precursors. The synthesis of the single aerogel involved the preparation of an alcogel by a two step sol-gel (16) route followed by ambient pressure drying. Initially, (TEOS) was diluted in methanol $(\mathrm{MeOH})$ and was partially hydrolyzed with water under acidic conditions with oxalic acid (Aldrich $98 \%$ purity), the sol was stirred for $1 \mathrm{~h}$ and kept for hydrolysis for $12 \mathrm{~h}$. The condensation of these hydrolyzed species was carried out in the presence of a base catalyst, $\mathrm{NH}_{4} \mathrm{OH}(1 \mathrm{M}$, Aldrich $98 \%$ purity). The solvent exchange was carried out with hexane and the surface chemical modification was done with hexamethyl-disilazane (HDMZ, Aldrich $98 \%$ purity) in hexane for $24 \mathrm{~h}$. Then, the gel was dried at ambient pressure at $200{ }^{\circ} \mathrm{C}$ for $2 \mathrm{~h}$. The synthesis of hybrid aerogel/ pseudowollastonite particles involved the same preparation; the difference was that, before the condensation of the species, the ceramic particles were added.

\subsection{Preparation of simulated body fluids (SBF and 1.5 SBF)}

Two simulated body fluids (17), one with an ion concentration nearly equal to that of human blood plasma (SBF) an other $50 \%$ more concentrated (1.5 SBF), were used (Table 1).

The solutions were prepared dissolving reagent grade chemicals of $\mathrm{NaCl}, \mathrm{NaHCO}_{3^{\prime}} \mathrm{KCl}, \mathrm{K}_{2} \mathrm{HPO}_{4} 3 \mathrm{H}_{2} \mathrm{O}, \mathrm{MgCl}_{2} 6 \mathrm{H}_{2} \mathrm{O}$, $\mathrm{CaCl}_{2} 2 \mathrm{H}_{2} \mathrm{O}$ and $\mathrm{NaSO}_{4}$ in desionized water and buffered to $\mathrm{pH} 7.4$ with $\mathrm{C}_{4} \mathrm{H}_{11} \mathrm{NO}_{3}$ and $1 \mathrm{~N} \mathrm{HCl}$ at $36.5^{\circ} \mathrm{C}$.

\subsection{Immersion of the aerogel and hybrid material in simulated body fluids}

The in vitro bioactivity assessment was performed by immersing samples in SBF for different periods of time (7, 14 and, 21 days) on the physiological conditions of $\mathrm{pH}$ and temperature. Each aerogel sample was immersed in $150 \mathrm{ml}$ of SBF and kept at $36.5^{\circ} \mathrm{C}$ in an incubator (18). It is important to mention that the shape of the samples for these tests was irregular. The dimensions of samples were of approximately $12 \pm 2 \mathrm{~mm}$ in length and $3 \mathrm{~mm} \pm 2$ in thickness.

As described below, the results obtained after performing the in vitro bioactivity assessment of the aerogels prepared in this work indicated a low bioactivity. Thus, in order to improve bioactivity a biomimetic method was used. This method consisted in the immersion of samples in SBF for 7 days followed by their immersion in 1.5 SBF for other 7or 14 days. In the last case (7 days in $\mathrm{SBF}+14$ days in $1.5 \mathrm{SBF}$ ), the $1.5 \mathrm{SBF}$ was replaced by fresh 1.5 SBF after one week.

At the end of the immersion periods, the aerogel and hybrid aerogel samples were removed from the flasks, gently washed with deionized water and dried at room temperature.

\subsection{Characterization methods}

The surface of silica aerogel and hybrid silica aerogel/ pseudowollastonite materials after immersion in SBF or after the biomimetic processing were analyzed by using an scanning electron microscope (SEM, Jeol JSM 6300, Japan) with an energy dispersive $\mathrm{X}$-ray spectroscopy attachment (EDS) and X-ray diffraction (XRD , Siemens D5000). The XRD analyses were performed by the $\mathrm{X}$-Ray Powder technique in the range of $10^{\circ}$ to $80^{\circ}$ in 2 theta $(\theta)$ using $\mathrm{Cu} \mathrm{K \alpha}(\lambda=0.15405 \mathrm{~nm})$ radiation at a rate of $2^{\circ} / \mathrm{min}$. Microstructural studies were performed using high-resolution transmission electron microscopy (HRTEM, FEI TITAN HRTEM), while infrared spectroscopy (IR, NICOLET 500) was employed to observe the growth of the phosphate groups $\left(\mathrm{PO}_{4}\right)^{3}$, which are characteristic groups of apatite. 


\section{RESULTS AND DISCUSSIONS}

Fig. 1 shows the FT-IR analysis of samples. The absorption band at $980 \mathrm{~cm}^{-1}$ corresponds to $\left(\mathrm{PO}_{4}\right)^{3}$ (19) groups and, at 3500 and $1600 \mathrm{~cm}^{-1}$, the stretching bands correspond to $\mathrm{O}-\mathrm{H}$. Regarding to the aerogels, at $850 \mathrm{~cm}^{-1}$ appears other band that corresponds to Si-C. The absorption bands at $2968 \mathrm{~cm}^{-1}$ and $1400 \mathrm{~cm}^{-1}$ correspond to asymmetric stretching vibration band of $\mathrm{C}-\mathrm{H}$ bonds (15), the last one appears at $1050 \mathrm{~cm}^{-1}$ and
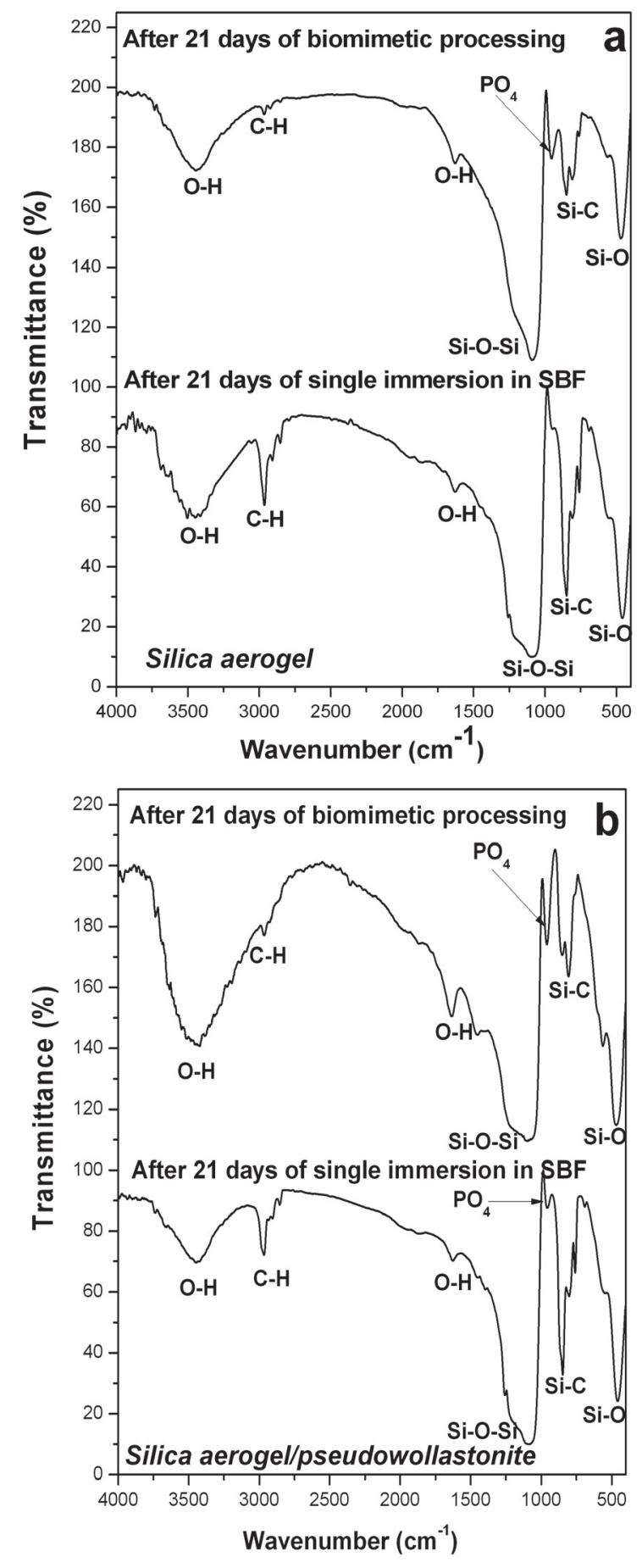

Figure 1. FT-IR spectra of the silica aerogel (a) and the hybrid silica aerogel/pseudowollastonite (b). indicates the asymmetric stretching of the intertetrahedral oxygen atoms in the Si-O-Si linkage (20). The presence of the $\left(\mathrm{PO}_{4}\right)^{3}$ and $\mathrm{O}-\mathrm{H}$ groups may indicate the formation of a bioactive compound on both the silica aerogel (Fig. 1a) and hybrid silica aerogel/pseudowollastonite (Fig.1b).

Fig. 2 shows some XRD patterns of the hybrid materials. As it can be observed in Fig. 2a, corresponding to the silica aerogel with no pseudowollastonite particles, an amorphous halo appears at an angle $2 \theta$ between 20 and 30 degrees corresponding to silica (21). After single immersion in SBF, Fig. 2b (bioactivity assessment), a small peak at an angle $2 \theta$ of 22 degrees, which corresponds to silica, can be observed, this same peak appeared on the untreated hybrid aerogel/pseudowollastonite material. However, no peaks corresponding to a new bioactive compound were detected by this technique on all the materials tested.

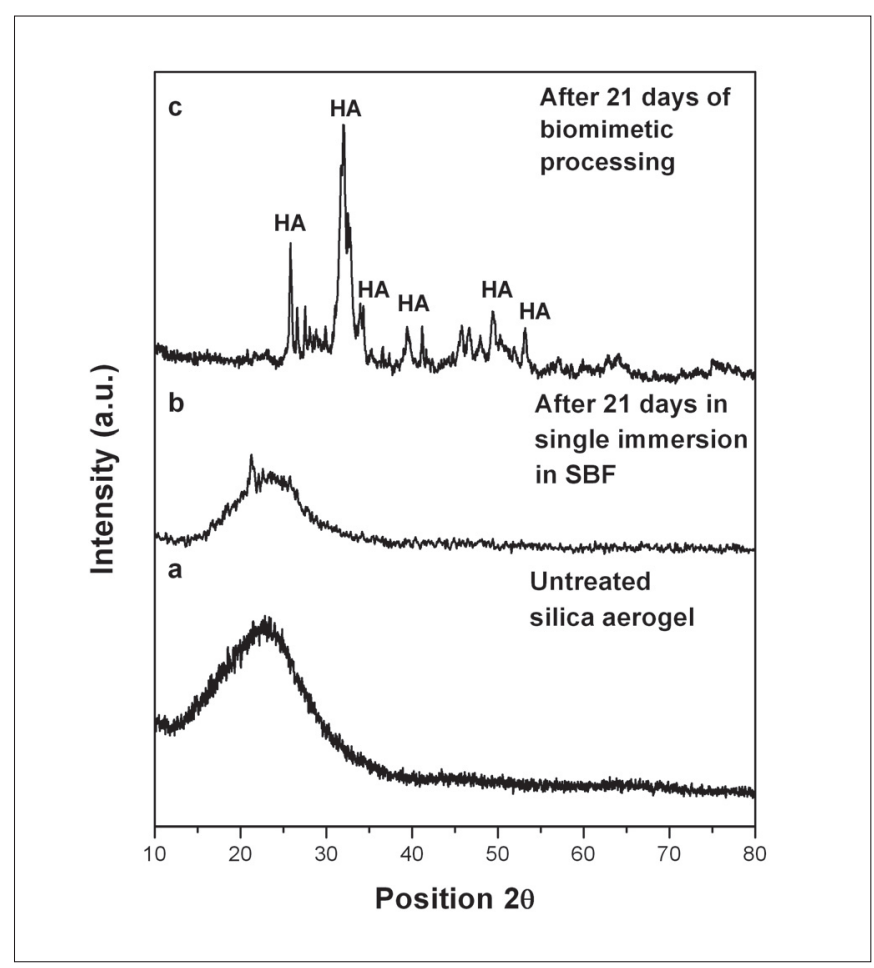

Figure 2. XRD patterns: untreated silica aerogel (a), hybrid silica aerogel/pseudowollastonite after 21 days of immersion in single SBF (b) and hybrid silica aerogel/pseudowollastonite after 21 days of biomimetic processing (c).

On the other hand, the formation of a compound identified as hydroxyapatite was formed on the biomimetically treated hybrid silica aerogel/pseudowollastonite after 21 days (Fig. 2c).

Fig. 3 shows SEM images and EDS spectra of both the silica aerogel and the hybrid silica aerogel/pseudowollastonite materials after the in vitro bioactivity assessment, that is, after 7 (Fig. 3a,d), 14 (Fig. 3b,e) and 21 days (Fig. 3c,f) of single immersion in SBF. In both samples, after 7 days, the corresponding EDS spectra corroborate the presence of only silica (Fig.3a,d). After 14 days, the Ca,P-rich nucleation begins on the silica aerogel, while the growth of this compound can be observed after the same period of time on the hybrid silica aerogel/ pseudowollastonite material (Fig.3b,e). The formation 


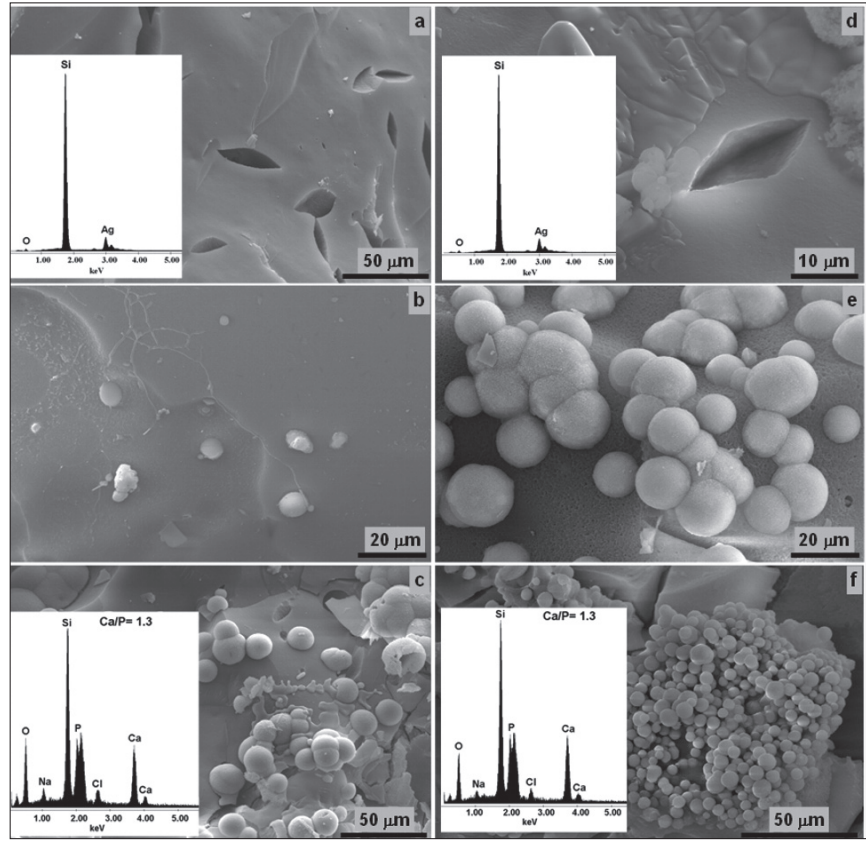

Figure 3. SEM images of aerogel without $(a, b, c)$ and with $(d, e, f)$ pseudowollastonite particles after: 7 (a-d), 14 (b-e) and 21 days of single immersion in SBF (c-f).

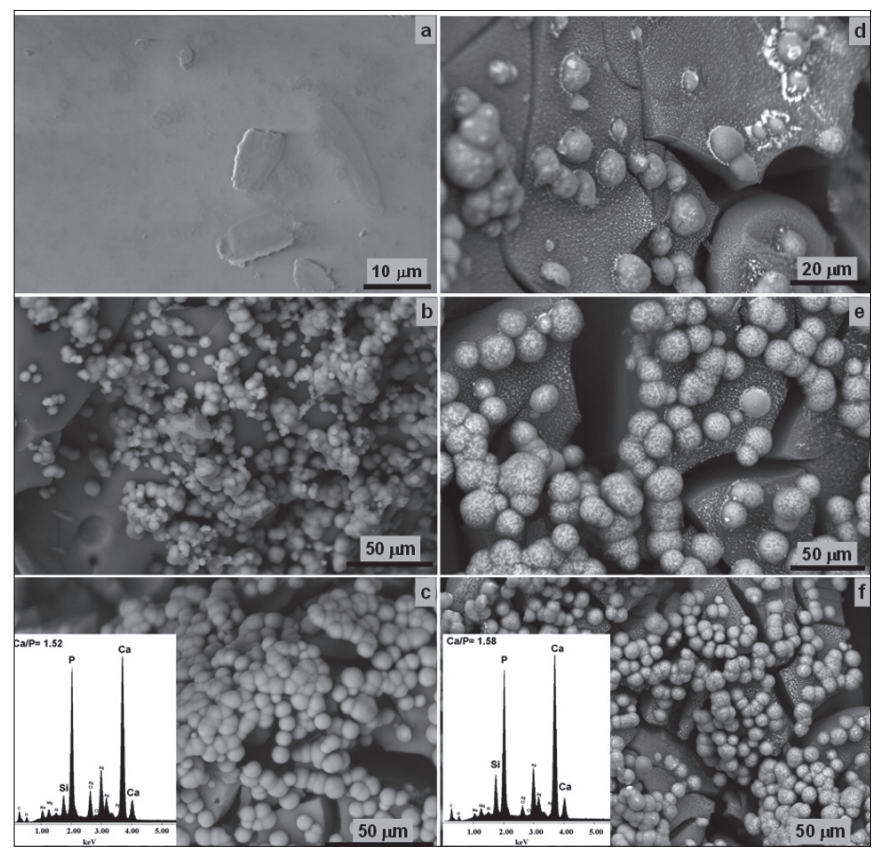

Figure 4. SEM images of the aerogel without $(a, b, c)$ and with $(d, e$, f) pseudowollastonite particles after the biomimetic treatment for: 7 days in SBF (a-d), 7 days in SBF +7 days in 1.5 SBF (b-e) and 7 days in $\mathrm{SBF}+14$ days in $1.5 \mathrm{SBF}$ (c-f).

of a Ca,P-rich compound on the silica aerogel and hybrid silica aerogel/pseudowollastonite particles after 21 days of single immersion in SBF (Fig. 3c,f) is demonstrated. According to the EDS analysis a compound with a $\mathrm{Ca} / \mathrm{P}$ ratio $=1.3$ was obtained, which may correspond to octacalcium phosphate (OCP) (22). It can be observed that the incorporation of pseudowollastonite particles promote the growth of the bioactive layer. These results indicate a low bioactivity of these hybrid materials and, as expected, a higher bioactivity
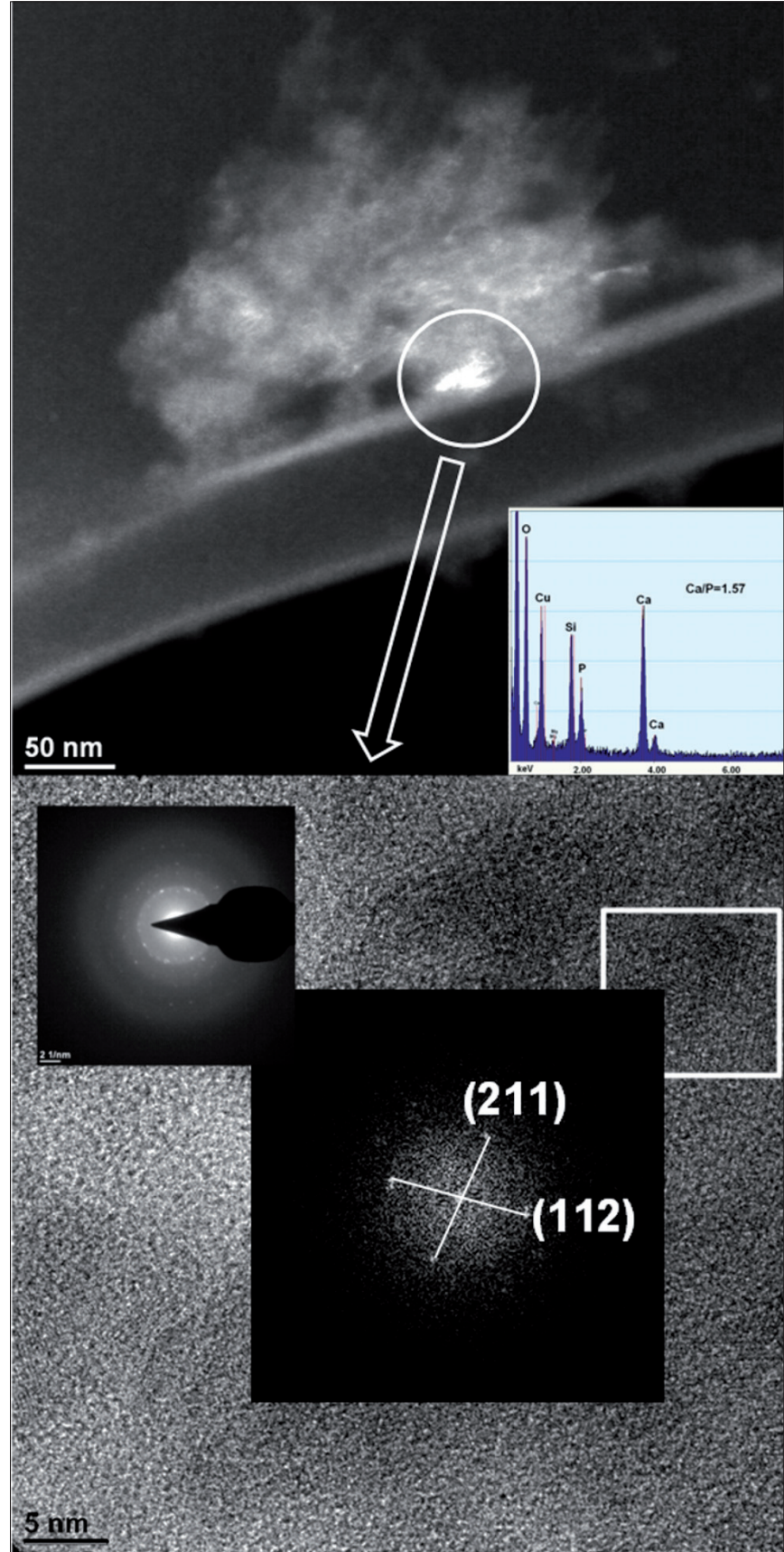

Figure 5. TEM micrograph, HRTEM and EDX analysis of the hybrid silica aerogel/pseudowollastonite after the biomimetic treatment for 21 days.

is observed on the hybrid silica aerogel/pseudowollastonite material

Figure 4 shows SEM micrographs of the bioactive layers formed on the aerogel without $(b, c)$ and with $(d, e, f)$ pseudowollastonite particles after being biomimetically treated for 21 days. On the sample shown in Figure 4a, no nucleation and growth of the $\mathrm{Ca}, \mathrm{P}$-rich compound occurred, since the first stage of the biomimetic process (7 days of immersion in single SBF) is equal to that of the in vitro bioactivity assessment. Thus, the morphology of this sample is similar to that shown in figure 3a. As indicated by the XRD analysis (Fig. 2c), a homogeneous apatite layer was formed on both aerogels when treated, whether the pseudowollastonite 
particles were present or not. The nucleation sites for the layer formed on the aerogel with pseudowollastonite particles was increased due to their presence. The bone-like apatite formation phenomenon occurs due to the high saturation of $1.5 \mathrm{SBF}$. It is possible that the formation of apatite nuclei occurs during the first stage of the biomimetic process (23), when the material is immersed in SBF. Subsequently, during the second stage, the more concentrated fluid (1.5 SBF) provides enough calcium and phosphate ions to promote the nuclei growth leading to the formation of a homogeneous and thick bone-like apatite layer.

The EDS spectra shown in Fig. 4c, $\mathrm{f}$ corresponds to the analysis within an area of the coating formed on the hybrid aerogels. These analyses prove that the compound formed on the surface of both materials is a Ca, P-rich compound with a $\mathrm{Ca} / \mathrm{P}$ atomic ratio within a range of 1.5-1.6, which was identified by XRD analysis as apatite.

A TEM image (Fig. 5) shows the morphologies of the hybrid silica aerogel/pseudowollastonite material after the biomimetic process. The HRTEM image shows the lattice fringes of (211) and (112) planes of hydroxyapatite crystals with the lattice spacing of about 0.292 and $0.289 \mathrm{~nm}$, respectively. This indicates that the growing layer on the surface of the aerogels composites corresponds to apatite (24). In order to verify the formation of apatite particles, EDX analyses were performed to evaluate the chemical composition, the analysis reveals a $\mathrm{Ca} / \mathrm{P}$ ratio $=1.57$ indicating the presence of a bonelike apatite.

These results indicate that the use of this biomimetic method improves the bioactivity of both aerogels, being this property higher for the pseudowollastonite-containing aerogel. Thus, the biomimetically treated aerogels obtained in this work are potential materials for biomedical applications.

\section{CONCLUSIONS}

Novel silica aerogel and hybrid silica aerogel/ pseudowollastonite materials were obtained by a two step sol-gel process followed by ambient pressure drying method. The in vitro bioactivity assessment performed by immersing samples in SBF for 21 days indicates a low bioactivity of both aerogels, although more agglomerates were formed on the hybrid silica aerogel/pseudowollastonite than those on the silica aerogel. In order to improve bioactivity, both aerogels were subjected to a biomimetic method consisting in the immersion of samples in SBF for 7 days, followed by the immersion in $1.5 \mathrm{SBF}$ for 14 days. An apatite layer was observed on the biomimetically-treated aerogels without and with pseudowollastonite particles. The thickness of the bonelike apatite layer increased when pseudowollastonite particles were added to the aerogel.

These results indicate that these aerogels can be highly potential biomaterials, especially, the hybrid silica aerogel/ pseudowollastonite.

\section{ACKNOWLEDGEMENTS}

We thank to CONACyT-Mexico for the scholarship 167991. This work was supported by CONACyT-Mexico through the project: $\mathrm{CO} 2-44830$

\section{REFERENCES}

1. Soleimani, D; Abbasi, M; (2008): Silica aerogel; synthesis, properties and characterization, J Mater Process Tech., 199, 10-26. http://dx.doi. org/10.1016/j.jmatprotec.2007.10.060

2. Hwang, S.W; Kim, T.Y; Hyun, S.H; (2010): Effect of surface modification conditions on the synthesis of mesoporous crack-free silica aerogel monoliths from waterglass via ambient-drying, Micropor Mesopor Mat., 130, 295-302. http: / / dx.doi.org/10.1016/j.micromeso.2009.11.024

3. Smitha, S; Shajesh, P; Aravind, P.R; Rajesh Kumar, S; Krishna Pillai, P; Warrier, K.G.K; (2006): Effect of aging time and concentration of aging solution on the porosity characteristics of subcritically died silica aerogels, Micropor Mesopor Mat., 91, 286-292.

4. Hench, L.L; (1998): Biomaterials: a forecast for the future, Biomaterials, 19(16) 1419-1423. http:/ / dx.doi.org/ 10.1016/S0142-9612(98)00133-1

5. Aza, P. N. de; Aza, A. H. de; Aza, S. de; (2005): Crystalline bioceramic materials Bol. Soc. Esp. Ceram. Vidr., 44 (3): 135-145. http://dx.doi. org/10.3989/ cyv.2005.v44.i3.382

6. Aza, P. N. de; Aza, A. H. de; Pena, P; Aza, S. de; (2007): Bioactive glasses and glass-ceramics Bol. Soc. Esp. Ceram. Vidr., 46 (2): 45-55. http:/ /dx.doi. org/10.3989/ cyv.2007.v46.i2.249

7. Vallet-Regi, M.; (2014): Ceramics in the world of biology Bol. Soc. Esp. Ceram. Vidr., 53 (2): 53-59. http:/ / dx.doi.org/ 10.3989/ cyv.82014

8. Carlisle, E. M.; (1970): Silicon: a possible factor in bone calcification. Science, 167 (3916): 279-280. http:/ / dx.doi.org/ 10.1126/ science.167.3916.279

9. Carlisle, E. M.; (1980): Biochemical and morphological changes associated with long bone abnormalities in silicon deficiency. J. Nutr., 110(5):10461056 .

10. Carlisle, E. M.; (1981): Silicon: a requirement in bone formation independent of vitamin D1. Calcif. Tissue Int., 33 (1): 27-34.

11. Martínez, I. M; Velásquez, P; Meseguer-Olmo, L; Aza, P. N. de (2011): Production and study of in vitro behavior of monolithic $\alpha$-tricalcium phosphate based ceramics in the system $\mathrm{Ca}_{3}\left(\mathrm{PO}_{4}\right)_{2}-\mathrm{Ca}_{2} \mathrm{SiO}_{4}$., Ceram Int., 37(7), 2527-2535. http:/ / dx.doi.org/ 10.1016/j.ceramint.2011.03.062

12. Cortés, D.A; Nogiwa, A.A; Almanza, J.M; Ortega, S; (2005): Biomimetic apatite coating on Mg-PSZ/ $\mathrm{Al}_{2} \mathrm{O}_{3}$ composites. Effect of the immersion method. Mat.Lett.,59, 1352-1355. http://dx.doi.org/ 10.1016/j. matlet.2004.12.040

13. Kokubo, T., Kim, H. M., Miyaji, F., Takadama, H., \& Miyazaki, T.; (1999): Ceramic-metal and ceramic-polymer composites prepared by a biomimetic process. Composites Part A: Applied Science and Manufacturing, 30(4), 405-409. http: / / dx.doi.org/ 10.1016/S1359-835X(98)00127-4

14. Jyoti, L; Gurav, A; Digambar, Y; Nadargi, A; Venkateswara, Rao.; (2008): Effect of mixed Catalysts system on TEOS-based silica aerogels dried at ambient pressure, Appl Surf Sci., 255 3019-3027. http://dx.doi. org/10.1016/j.apsusc.2008.08.059

15. Jyoti, L; Gurav, A; Venkateswara, Rao; Uzma Bangi, K.H.; (2009): Hydrophobic and low density silica aerogels dried at ambient pressure using TEOS precursor., J Alloy Compd., 471, 296-302. http://dx.doi. org/10.1016/j.jallcom.2008.03.076.

16. Brinker, C.J; Sherer, G.W (Eds.). (1990): Sol Gel science, The Physics and Chemistry of Sol-Gel Processing. Gulf Professional PublishingAcad.

17. Kokubo, T; Shigematsu, M; Nagashima, Y; Tashimiro, M; Nakamura, T; Yamamuro, T; Hagasho, S.; (1982): Apatite and Wollastonite containing glass ceramics for prosthetic applications., Bull Inst Chem Res., Kyoto Univ. 60, 3-4.

18. Kokubo, T., \& Takadama, H. ;(2006): How useful is SBF in predicting in vivo bone bioactivity?., Biomaterials, 27(15), 2907-2915. http:/ / dx.doi.org/ 10.1016/j.biomaterials.2006.01.017

19. Fathi, M. H; Hanifi, A; Mortazavi, V. ;(2008). Preparation and bioactivity evaluation of bone-like hydroxyapatite nanopowder. J Mater Process Tech., 202(1-3), 536-542. http:/ / dx.doi.org/ 10.1016/j.jmatprotec.2007.10.004

20. Rao, A. V; Gurav, A. B; Latthe, S. S; Vhatkar, R. S; Imai, H; Kappenstein, C; Wagh, P.B; Gupta; (2010): Water repellent porous silica films by sol-gel dip coating method, J Colloid Interf Sci., 352(1), 30-35. http:/ / dx.doi.org/ $10.1016 /$ j.jcis.2010.08.003

21. Lukito, D; Xue, J.M; Wang, J.; (2005): In vitro bioactivity assessment of 70 (wt.) $\% \mathrm{SiO}_{2}-30$ (wt.) \% CaO bioactive glasses in simulated body fluid, Mater Lett., 59(26), 3267-3271. http:/ / dx.doi.org/10.1016/j.matlet.2005.05.055

22. Nogiwa, A. A; Cortés, D. A.; (2006): Bone-like apatite coating on Mg-PSZ/ $\mathrm{Al}_{2} \mathrm{O}_{3}$ composites using bioactive systems, J Mater Sci: Mater M., 17, 11391144. http:/ / dx.doi.org/ 10.1007/s10856-006-0541-8

23. Hata, K; Kokubo, T; Nakamura, T; Yamamuro, T.; (1995): Growth of a bonelike apatite layer on a substrate by a biomimetic process., J Am Ceram Soc., 78(4), 1049-1053. http: / / dx.doi.org/ 10.1111/j.1151-2916.1995.tb08435.x

24. Deng, Y; Sun, Y; Chen, X; Zhu, P; Wei, S.; (2013): Biomimetic synthesis and biocompatibility evaluation of carbonated apatites template-mediated by heparin., Mat Sci Eng C-Mater., 33(5), 2905-2913. http://dx.doi.org/ 10.1016/j.msec.2013.03.016

Recibido: 26/03/2014

Recibida versión corregida: 20/08/2014

Aceptado: 21/08/2014 